\title{
Review: An example of students who can self- assess themselves and work autonomously, by Juan Carlos Araujo Portugal
}

\author{
Burgos, Universidad de Burgos: Estudios y monografías, 62, 210 pp., \\ $€ 21.34$, ISBN 978-84-16283-49-1, \\ bttps://www3.ubu.es/ubuespacio/?attachment id=4967
}

Jelena Marjanovic

Universitat Autonoma de Barcelona

The book An example of students who can self-assess themselves and work autonomously by Juan Carlos Araujo Portugal centers around the author's empirical research on learner self-assessment and autonomous work. Self-assessment and learner autonomy are described as crucial concepts in technology-enhanced language learning by the author. Using a mixed-methods approach, Portugal delves into the learning process of his own students from an English teacher-researcher perspective. He focuses on exploring the following issues: the accuracy of his students' self-assessment of their English competence (their strengths and weaknesses) in light of their final marks, his students' uptake of the information on their weaknesses (whether they take action to improve them or not), and student perceptions of whether they have become more autonomous learners in the specific technologyenhanced learning set-up and how they might have achieved that. Portugal used qualitative methods to investigate his students' ability to self-assess their strengths and weaknesses in English and a mix of quantitative and qualitative methods to analyze their learner autonomy manifested in the use of the course wiki. The instruments he used were the student self-assessment reports, the final exam grades, 
and a post-course questionnaire measuring his students' perception of effectiveness of the wiki and their own progress in autonomous learning.

The issues covered in this book are undoubtedly topical. In the $21^{\text {st }}$ century, learner autonomy and the ability to self-assess (as well as self-regulate and selfdirect one's learning) are seen as requirements for lifelong learning and satisfaction (Council of Europe, 2016). At the same time, new technologies are frequently described as potentially facilitative of autonomous learning and student engagement, especially in the foreign language learning context (e.g. Levy, 1997). However, the meanings of autonomy and related self-concepts are still elusive at best. Holec (1981, p. 3) first defined autonomy as the "ability to take charge of one's learning" and others have built on this definition by proposing more elaborated conceptualizations (Benson, 2007; Little, 2007; Littlewood, 1996; Reinders, 2010) . Nevertheless, a consensus on what autonomous learning means has not been reached. In Portugal's book, autonomous learners are described as those who, among other things, "draw on their intrinsic motivation when they accept responsibility for selfmanagement in learning; and success in learning strengthens their intrinsic motivation” (p. 42). Self-assessment is an essential process in autonomous learning, Portugal argues, and both self-assessment and autonomy should be seen as transferable skills that ought to be fostered.

The book opens with Portugal's introduction of the concepts of self-assessment and learner autonomy and description of their importance, not only for the $21^{\text {st }}$ century learners, but for contemporary world citizens, as well. He further describes his motivation to conduct the study which, according to him, comes from a personal belief in self-assessment and autonomous work as powerful tools in education. He concludes the introduction by describing the context and laying out the hypotheses and predictions that guided the study.

In Chapter 2, entitled Assessment, the role of assessment in education and learning processes in general is discussed. Portugal brings in a somewhat political critique of the status of assessment in today's education - it is far from being a priority on educational agendas, Portugal claims. The author furthermore expresses his concerns about the transferability of the skills that are taught and assessed nowadays. His stance is clear: there are more useful ways of assessment than the ones we are currently using in foreign language education. Specifically, the author proposes that assessment need not only be used for evaluating learning outcomes, but also can be purposefully employed as a strategy for learning that contributes to achieving those outcomes. At the same time, he acknowledges the issue 
of the accuracy and reliability of self-assessment. The message Portugal seems to want to send is that self-assessment can be a reliable form of assessment if students take it seriously and if they are taught how to do it properly. Another highlight of this chapter is the in-depth description of the concepts that are seen as related to autonomy and self-assessment, such as self-confidence, self-beliefs, and self-regulation.

In Chapter 3, entitled New approaches to teaching, the author shifts his focus to other central constructs of his study. He explores learner autonomy (including the importance of self-directed goal setting) and new technologies (e.g. characteristics of wikis) and how to use them for learning. It is in this chapter that the author explains the link between learner autonomy and self-assessment as he sees it: learner autonomy can be seen as being mediated by self-assessment. Goal setting is presented as another mediator of learner autonomy and is also linked to selfevaluation as, according to the author, setting goals autonomously only makes sense if self-assessment of the attainment of these goals is done as well. The author also provides an exhaustive list of affordances of wikis, the digital tool he used in his study, as applicable to various contexts. The affordances include potential for collaborative work primarily, but also learner agency. In addition, different types of uses of wikis are presented. These detailed accounts of technology affordances make this chapter a useful manual on how to use wikis in classrooms. Some concrete tips can be identified, for example, on how to use wikis to determine learning styles and produce learner statistics. The chapter finishes with a discussion of the digital natives vs. digital immigrants dichotomy which sheds light on some potentially erroneous ways we tend to label technology users. Finally, an alternative, more realistic categorization of learners-technology-users is proposed in the context of this study.

Having theoretically reviewed the concepts relevant for his research, the author moves to Chapter 4, Research study, where he describes his empirical study. The mixed-method and the data collection tools employed in the study are described in detail, including the central instrument, a self-devised student record card. (The data collection tools are fully provided in the Appendices chapter.) The overall study objectives are concisely presented in light of the theoretical framework outlined in the previous chapters. In addition, the author endeavors to depict the universal value of the study objectives and their relevance to $21^{\text {st }}$ century learning. 
Chapter 5 of this book is dedicated to the study results. The author opted to present the quantitative results in a tabular mode. The tables compare two groups of students and show the relative differences between their subjective and objective assessment of their English language skills and competences - their selfreports and final exam results. The influence of the factors of age and gender is also presented. The second part of the results presentation is about measuring learner autonomy development. It depicts the students' perceptions of their autonomous learning development and outcomes and suggestions of ways to become more autonomous learners.

The following book section, Chapter 6, contains the discussion of the results. The results for each research question are discussed and limitations are simultaneously presented. The author shows consideration of certain study flaws related to the study design and further reflects on his data collection methodology, suggesting ways to improve the design in future studies.

Chapter 7 presents the study conclusions, while Chapter 8 lists the bibliography used in the study. Chapter 9 contains the appendices, which include the data collection instruments (students record card and the questionnaires), some information about the participants, types of final exam tasks, and self-assessment outcomes.

Overall, the book offers various contributions to the field of English as a foreign language research and pedagogy. First and foremost, the author promotes exploration of self-assessment and autonomous learning as two important competences for the $21^{\text {st }}$ century learner. He calls for inclusion of self-assessment in essential elements of the learning process and explore its effectiveness not just as an evaluation method, but as a learning strategy, as well. Next, it has been suggested that autonomous learning may only be suitably looked at as inseparable from its context; hence, Portugal's study represents a valuable snapshot of one large case of learner autonomy that can complement similar studies done in different contexts. The book also illustrates the benefits of conducting research in one's class as a teacher. Another commendable point is the author's effort in reviewing the pertinent literature. However, at the same time, the connection between some concepts presented as interrelated (e.g. autonomy and self-assessment, self-direction, selfefficacy, etc.) is not always well described. The book would benefit from introducing more arguments that establish a strong link between these concepts. Another weakness is the lack of a clearly defined conceptual framework for exploring learner autonomy, which could be improved by identifying early on what exactly 
is considered as manifestation of autonomy in the study. This is especially important in light of the study aim to determine whether development of autonomy happened in the studied context. The distinction between autonomous work and autonomous learning (e.g. autonomous use of digital tools for learning vs. autonomous attaining learner objectives) could also be emphasized more effectively.

Undoubtedly, the book has a strong pedagogical value, too. The research presented in the book has pedagogical implications for implementation of innovative methods of learning and promoting autonomy in the classroom. The pedagogical tools used in the study (e.g. the student record card) can be replicated in other classrooms to promote student self-reflection and independent critical thinking. In that sense, even though Portugal's empirical study may be the central focus of the book, an implicit story is also told in parallel: that of an English language teacher who agentively devised his own technology-enhanced methods to foster self-assessment and autonomous learning in his classroom. As such, it can serve as inspiration to many teachers and educational researchers alike.

\section{REFERENCES}

Benson, P. (2007). Autonomy in language teaching and learning. Language Teaching, 40(1), 2140. https://doi.org/10.1017/S0261444806003958.

Council of Europe. (2016). Competence for democratic culture: Living together as equals in culturally diverse democratic societies. Executive summary. https://doi.org/10.1080/15235882.1992.10162628.

Holec, H. (1981). Autonomy and foreign language learning. Oxford: Pergamon.

Levy, M. (1997). Computer-assisted language learning: context and conceptualization. Oxford: Clarendon Press.

Little, D. (2007). Language learner autonomy: Some fundamental considerations revisited. Innovation in Language Learning and Teaching, 1(1), 14-29. https://doi.org/10.2167/illt040.0

Littlewood, W. (1996). Autonomy: An anatomy and a framework. System, 24(4), 427-435. https://doi.org/10.1016/S0346-251X(96)00039-5

Reinders, H. (2010). Towards a classroom pedagogy for learner autonomy: A framework of independent language learning skills. Australian Journal of Teacher Education, 35(5), 40-55. http://dx.doi.org/10.14221/ajte.2010v35n5.4 


\section{JELENA MARJANOVIC}

Jelena Marjanovic is currently a PhD student at Universitat Autònoma de Barcelona (expected graduation 2021). Her work focuses on technology-enhanced autonomous learning. She holds an MPhil in Education from the university of Cambridge, UK and has been working in the language teaching, curriculum design and instructional design fields for ten years.

email@email.com

https://orcid.org/0000-0002-6997-5522

Marjanovic, Jelena (2020). Review: An example of students who can self-assess themselves and work autonomously, by Juan Carlos Araujo Portugal. Bellaterra Journal of Teaching \& Learning Language \& Literature, 13(4), e818. https://doi.org/10.5565/rev/jt13.818

https://revistes.uab.cat/jtl3/ 